\title{
Deformation Rules for Surrounding Rock in Directional Weakening of End Roofs of Thin Bedrocks and Ultrathick Seams
}

\author{
Fei Liu $\mathbb{D}^{1,2}$ Zhanguo Ma $\mathbb{D}^{1},{ }^{1}$ Yongsheng Han, ${ }^{3}$ and Zhimin Huang ${ }^{4}{ }^{4}$ \\ ${ }^{1}$ State Key Laboratory for Geomechanics and Deep Underground Engineering, School of Mechanics and Civil Engineering, \\ China University of Mining \& Technology, Xuzhou, Jiangsu 221116, China \\ ${ }^{2}$ School of Resources and Civil Engineering, Suzhou University, Suzhou, Anhui 234000, China \\ ${ }^{3}$ Department of Water Resources Engineering, Shandong Water Conservancy Vocational College, Rizhao, \\ Shandong 276826, China \\ ${ }^{4}$ School of Materials and Physics, China University of Mining \& Technology, Xuzhou, Jiangsu 221116, China
}

Correspondence should be addressed to Zhanguo Ma; zhgm1044@126.com

Received 23 June 2020; Revised 9 August 2020; Accepted 26 August 2020; Published 9 September 2020

Academic Editor: Zhiqiang Yin

Copyright (C) 2020 Fei Liu et al. This is an open access article distributed under the Creative Commons Attribution License, which permits unrestricted use, distribution, and reproduction in any medium, provided the original work is properly cited.

With the deployment of China's energy strategy in the western regions, complex geological mining conditions such as thin bedrock and ultrathick seams in western China have caused a series of problems such as serious deformation of the surrounding rock at the ends of the working face and the increase in the lead abutment pressure of the roadways; the research on end roof deformation in the resource exploitation in western China has become one of the great demands of the industry. Based on the failure characteristics of rock mass, relying on the actual mining geological conditions of a coal mine in Inner Mongolia, the failure characteristics of the overlying rock strata under the influence of mining were simulated and analyzed using similar material simulation experiment, which intuitively reproduced the failure and deformation processes of the immediate roof, main roof, and key strata and revealed the mechanical mechanism of the directional weakening of the end roof. It is of great significance for the stability control of the surrounding rock at the end of the fully mechanized caving face in the thin bedrocks and ultrathick seams, reducing the abutment pressure of gate roadway and controlling the spontaneous combustion of residual coal in the goaf.

\section{Introduction}

The "13th Five-Year Plan" determines that China's energy production layout will continue to move westward, and the western region is still the main position of China's energy production [1]. The open roof area of the upper and lower ends of the fully mechanized caving face is large, which is located at the superposition of the strike support pressure and the inclined abutment pressure of the stope. The special geological conditions such as ultrathick seam and thin bedrock in the West further lead to a series of problems, such as serious deformation of surrounding rock at the end (as shown in Figure 1), increase of advance abutment pressure of roadway $[2,3]$, and low resource recovery rate $[4,5]$ of working face. The existing roof deformation control theory is difficult to ensure the safe and efficient production of western mines. In order to effectively control the deformation of surrounding rock at the ends, a lot of research work has been carried out on the mechanical mechanism of deformation of end roof at home and abroad in recent years, and a large number of theoretical and technical application results have been obtained. Xiao [6] studied the structural stability of the ends of the fully mechanized caving face and believed that the supports at the ends of top-caving mining face are the difficult points for stope support and the main reason lies in the formation and stability of the arc triangle plate at the ends; Liu [7] studied the support technology at the ends of longwall fully mechanized caving face in steep thick seams; Yang and Liu [8] analyzed the caving form of the overlying strata at the ends with the method of theoretical calculation; Fang et al. [9] established the structural mechanics module of the end triangle area and analyzed the 


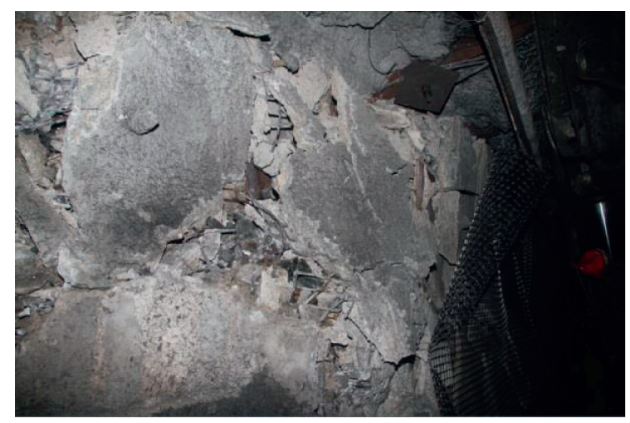

FIGURE 1: Deformation diagram of surrounding rock of end roofs in test area.

mechanism of instability and failure of the arc triangle area; the scholars Sellers and Klerck [10] have found through study that the discontinuous surface generated inside the surrounding rock due to fissures and weak faces in the surrounding rock of the roadway as well as the discontinuity surface created by joint connection in the surrounding rock is one of the main reasons for the fracture spacing in the surrounding rock of the roadway. The presplitting pressure relief technology is [11] a technique to change the physical and mechanical properties of the rock mass through artificial intervention such as hydraulic fracturing or presplitting blasting, so as to weaken the structural strength of the coal rock mass and increase the fissure content, thereby achieving the purpose of permeability improvement or pressure relief. The presplitting pressure relief technology has been widely used in the prevention and control of low-permeability coal seam gas extraction, rock burst, and the control of surrounding rock in mining space $[12,13]$. Dai [14] believes that presplitting blasting can eliminate the hinging effect between the fractured rocks of a hard roof, thereby promoting caving of the roof.

On-site exploration has the advantages of trustworthiness and reliability, but it features long cycle, heavy workload, high cost, and difficulty in grasping the main factors for mechanism analysis. The empirical formulas and theoretical analysis are simple and easy to operate, but there are larger calculation errors in related engineering due to the difficulty in generalization of complex mining geological conditions. A similar simulation [15-17] has the advantages of high efficiency, strong intuitiveness, good repeatability, good flexibility, and so on and can simulate the continuous dynamic deformation and failure process of the rock stratum. Therefore, in order to further investigate the deformation rules of surrounding rock in directional weakening of end roofs, in this paper, a similar material simulation experiment was used, based on the failure characteristics of rock mass and relying on the actual mining geological conditions of a coal mine in Inner Mongolia, to simulate and analyze the failure characteristics of the overlying rock strata under the influence of mining; it intuitively reproduced the failure and deformation processes of the immediate roof, main roof, and key strata and revealed the mechanical mechanism of the directional weakening of the end roof, which is of great significance for the stability control of the surrounding rock at the end of the fully mechanized caving face in the thin bedrocks and ultrathick seams, the improvement of the mining rate of coal resources, the reduction of the abutment pressure of gate roadway, and the control of the spontaneous combustion of residual coal in the goaf.

\section{Engineering Geological Conditions}

The surface of the well field in Ordos Loess Plateau of the western regions is overlaid by a large area of loess and aeolian sand, and the bedrock is exposed only in larger gullies. With complex terrain and criss-cross ravines and gullies, this region has well-developed dendritic gullies. The general trend of the terrain is high in the southwest and low in the northeast at an altitude of about $1127-1346 \mathrm{~m}$, with an altitude difference of $219 \mathrm{~m}$. Number 6 coal seam is mainly mined in the minefield. The minable thickness of the coal seam ranges from 6.05 to $35.50 \mathrm{~m}$, with an average thickness of $16.0 \mathrm{~m}$, belonging to stable to relatively stable coal seams. The structure of the coal seam has a complex structure, soft in the middle, hard at the top, relatively hard at the bottom, and being with developed fissures and a lot of dirt bands. The coal seam roof is mainly semihard and has a relatively high proportion of soft rock on the floor, most of which is mudstone, claystone, and carbonaceous mudstone. Detailed lithological descriptions of the rock strata are illustrated in Figure 2.

\section{Design of Similar Simulation Test}

3.1. Model Bench and Related Instruments. A bench designed independently by China University of Mining and Technology was adopted to establish a similar simulation test model in which a high-speed static strain collection system was used to record the changes in the pressure cell data during the mining process, changes in rock formation displacement were observed with digital photographic measurement technology, and a hydraulic loading system was used to pressurize the overlying rock strata. PhotoInfor [18-20], a practical software system for digital photography measurement developed by China University of Mining and Technology, was used for digital image analysis. The test system is shown in Figure 3.

3.2. Similar Model Parameters. This test simulated the rock strata with a total thickness of $112.9 \mathrm{~m}$ from the coal seam floorcoal seam roof of the coal seam, with a coal seam thickness of $16 \mathrm{~m}$. The cross section of the simulated roadway is rectangular, with a width of $5.5 \mathrm{~m}$, a height of $3.7 \mathrm{~m}$, and a cross-sectional area of $20.35 \mathrm{~m}^{2}$. The model geometric similarity ratio $\alpha_{l}=$ $\left(y_{m} / y_{p}\right)=\left(z_{m} / z_{p}\right)=(1 / 100)$, bulk density similarity coefficient [15] $\alpha_{\gamma}=\left(\gamma_{m i} / \gamma_{p i}\right)=0.65$, elastic modulus similarity coefficient $[15,21] \alpha_{E}=(1 / 154)$, and time coefficient of $1 / 10$ were taken. Similar materials are shown in Figure 4.

3.3. Similar Material Compounding Ratio. Based on the determination of the strength of the site rock strata, combined with the principle of similar simulation test, 


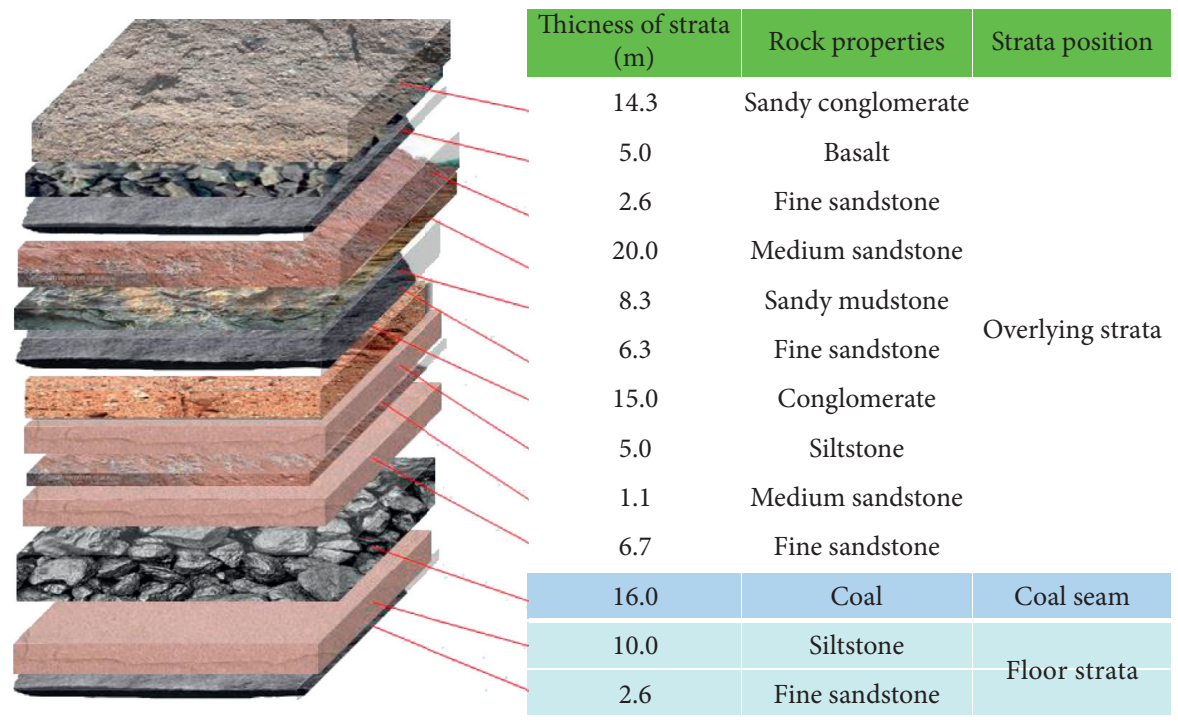

FIgURE 2: Lithological descriptions of the rock strata at number 6 coal seam.

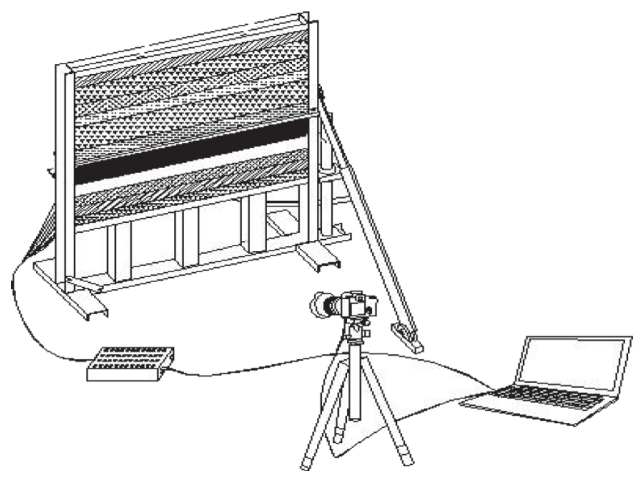

(a)

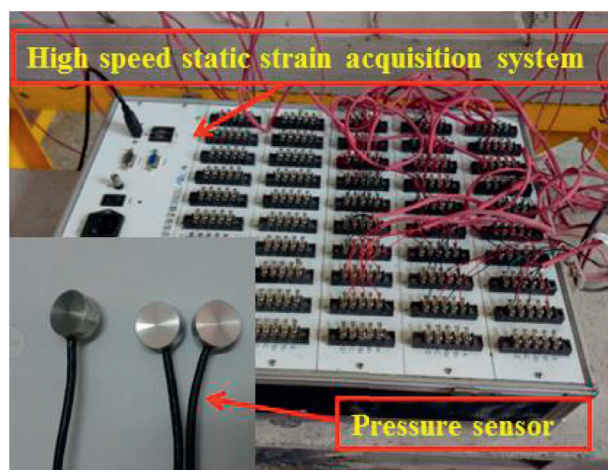

(b)

Figure 3: Test equipment. (a) Digital photogrammetric system and (b) rock stress collection system.

the strength of each layer in the model test was calculated. Ordinary fine-grained river sand (with a particle size of less than $3 \mathrm{~mm}$ ) was selected as aggregate, and gypsum and calcium carbonate were used as cementing materials. For the strength of similar materials in [22-24], a test specimen with a reasonable compounding ratio was prepared for a strength verification test (as shown in Figure 5), and the parameters of each stratified material ratio in this model were finally determined as shown in Table 1.

3.4. Test Method and Arrangement of Measuring Points. This test studied the effect of changes in topping angle on pressure release from excessive pressure of coal pillars in the section between F6203 and F6024 working faces and the roadway of the F6204 working face caused by overlength suspension roof at the ends of the goaf for F6203 working face. The $30^{\circ}, 45^{\circ}$, and $60^{\circ}$ fissures were prefabricated in the overlying rock strata on the side of F6203 working face from the angle of auxiliary transportation roadway on F6204. During the mining process, by caving of the overlying rock strata along the prefabricated fissures, the stress changes before and after the caving were analyzed. The pressure measuring points and displacement measuring lines were arranged as shown in Figure 6. There were three rows of pressure cells placed from bottom to top. The pressure cells in bottom row were numbered from A1 to A6 from left to right, the ones in the middle row were numbered from $\mathrm{B} 1$ to $\mathrm{B} 6$, and the ones in the top row were numbered from $\mathrm{C} 1$ to $\mathrm{C} 6$.

During the test, the model was excavated from left to right, the width of three hydraulic supports was collected, and then the top coal was drawn once for sublevel caving. Since the roof deformation is relatively large and the model stability time is relatively long during the period of drawing top coal for mining, when the drawing has a significant effect on the stress and deformation of the surrounding rock at the ends and the coal pillars in sections, stability time of 0.5 to $1.0 \mathrm{~h}$ is required for each measurement within the model. 


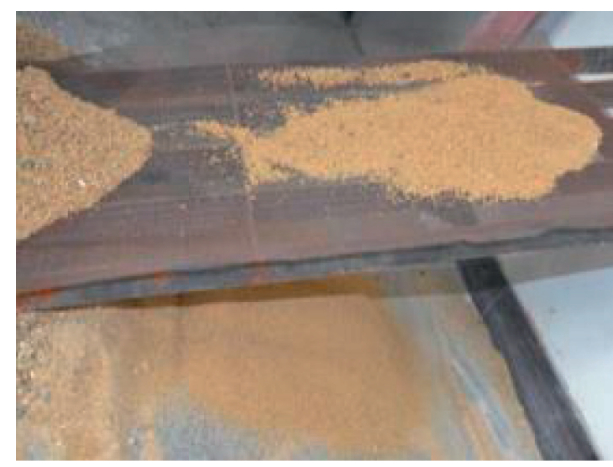

(a)

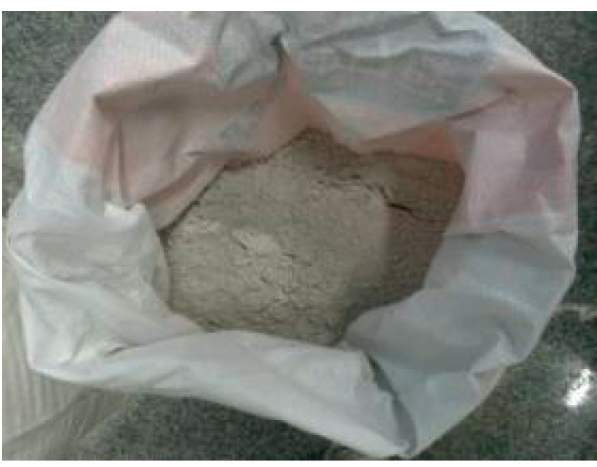

(b)

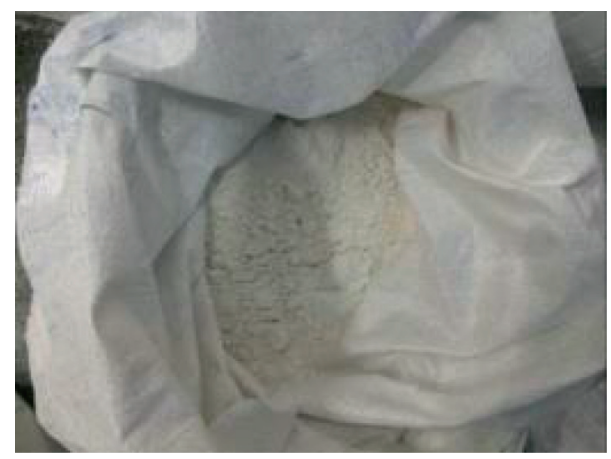

(c)

Figure 4: Similar materials. (a) River sand, (b) gypsum powder, and (c) calcium carbonate powder.

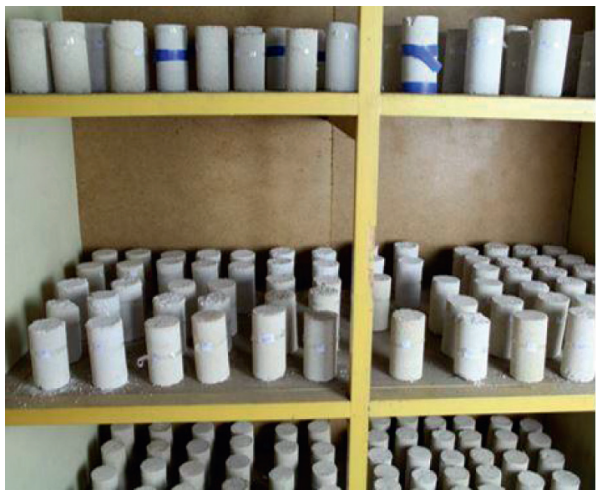

(a)

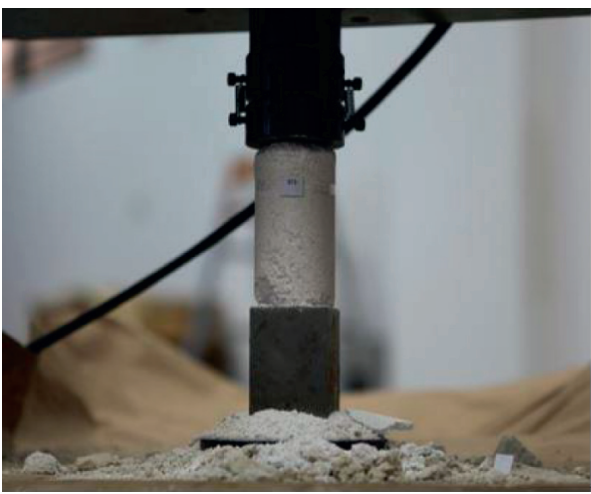

(b)

FiguRE 5: Strength test of similar materials [1]. (a) Sample of similar material and (b) strength test process.

\section{Deformation Rules for Overlying Strata in the Fully Mechanized Sublevel Caving Face with the Thin Bedrock and Ultrathick Seam}

4.1. Analysis on Limit Breaking Distance of Immediate Roof. After the coal seam is mined, the immediate roof will partially overhang. As the working face advances forward, the overhanging area continues to increase. When the suspension part of the immediate roof reaches a certain length, fracture failure will occur. The fracture forms of immediate roof are shown in Figure 7.
Figure 7 is a diagram of two fracture processes of immediate roofs. Through measurement and analysis, it can be determined that the limit fracture distance of the immediate roof is about $13 \mathrm{~m}$ and the fracture angle is about $63^{\circ}$ in the test area.

4.2. Deformation Analysis of Overlying Rock Strata Structure with Caving of the Main Roof. In this test, PhotoInfor image processing software was used to track and analyze the displacement of the rock strata, and the displacement was calculated according to the pixel coordinates in the image. 
TABLE 1: Ratio parameters of layered materials.

\begin{tabular}{|c|c|c|c|c|c|c|}
\hline Rock layer name & Depth of stratum (m) & Model thickness $(\mathrm{cm})$ & Sand $(\mathrm{kg})$ & Calcium carbonate $(\mathrm{kg})$ & Gypsum (kg) & Total mass $(\mathrm{kg})$ \\
\hline Glutenite & 14.3 & 14.3 & 32.84 & 2.53 & 2.53 & 37.89 \\
\hline Basalt & 5 & 5 & 11.59 & 1.32 & 0.33 & 13.25 \\
\hline Fine sandstone & 2.6 & 2.6 & 5.97 & 0.64 & 0.28 & 6.89 \\
\hline Medium sandstone & 20 & 20 & 44.16 & 4.42 & 4.42 & 52.99 \\
\hline Sandy mudstone & 8.3 & 8.3 & 19.24 & 1.92 & 0.82 & 21.99 \\
\hline Fine sandstone & 6.3 & 6.3 & 11.13 & 1.11 & 4.45 & 16.69 \\
\hline Conglomerate & 15 & 15 & 35.77 & 3.18 & 0.79 & 39.74 \\
\hline Siltstone & 5 & 5 & 10.60 & 0.79 & 1.85 & 13.25 \\
\hline Medium sandstone & 1.1 & 1.1 & 2.55 & 0.11 & 0.26 & 2.91 \\
\hline Siltstone & 6.7 & 6.7 & 15.02 & 1.91 & 0.82 & 17.75 \\
\hline Coal & 16 & 16 & 37.09 & 2.12 & 3.18 & 42.39 \\
\hline Siltstone & 10 & 10 & 22.42 & 1.22 & 2.85 & 26.50 \\
\hline Fine sandstone & 2.6 & 2.6 & 4.59 & 0.69 & 1.61 & 6.89 \\
\hline
\end{tabular}

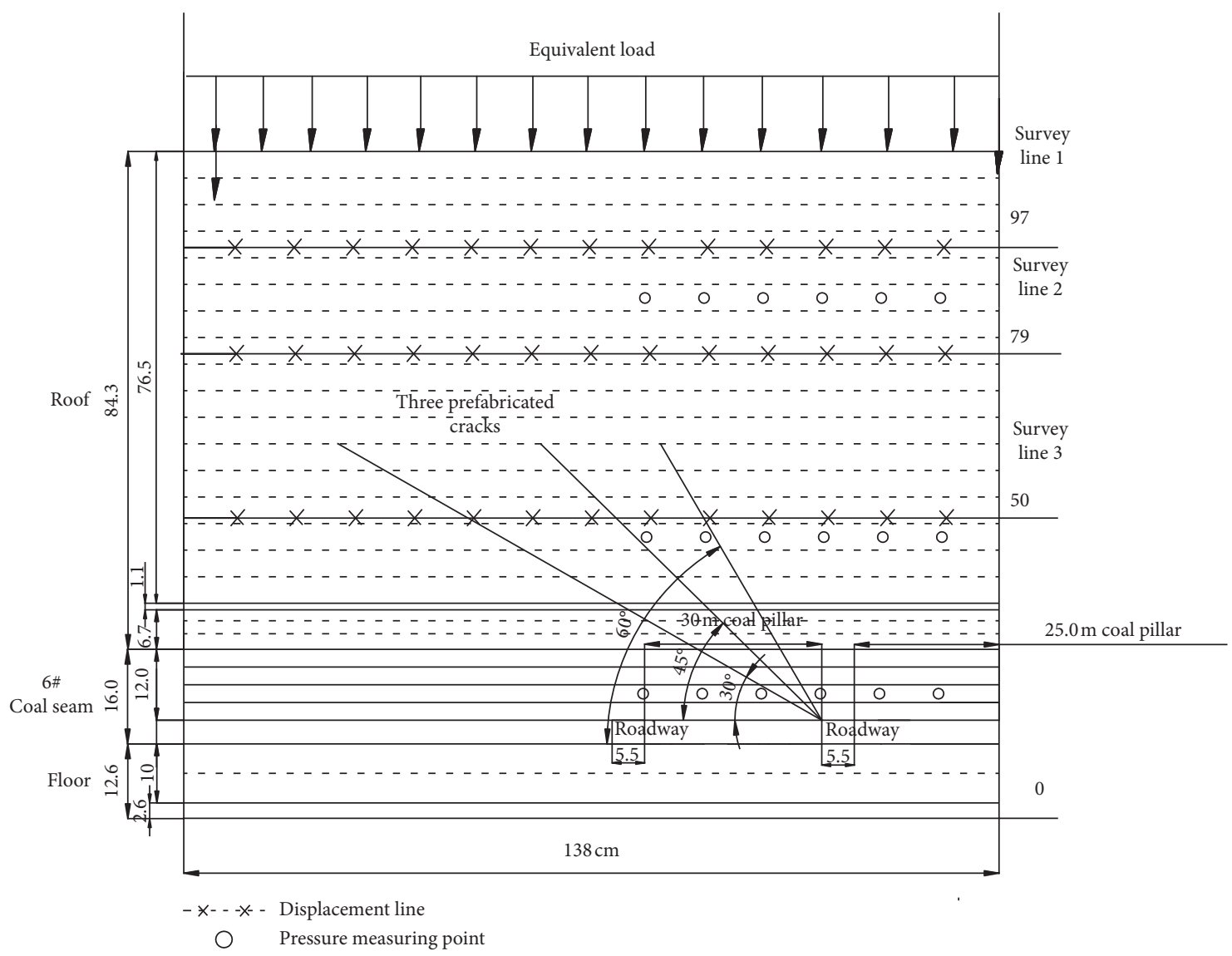

FIGURE 6: Layout of measuring points and lines of prefabricated roof fracture.

The output results were converted from pixel coordinates to actual coordinates, and the measured width of the model image of 2500 pixels was equivalent to the actual model width of $138 \mathrm{~cm}$ for displacement treatment. Grid partitioning is shown in Figure 8.

4.2.1. Analysis on the Test Process and Model Displacement Vector Cloud Diagram. The fracture test process diagram and model displacement vector cloud diagram for the main roof are shown in Figures 9 and 10.
As shown in Figures 9 and 10, it can be found that with the advancement of the working face, the overlying rock strata on the working face have undergone three processes of "separation-caving-compacting." The greater the cracking degree of the lower rock strata is, the smaller the cracking of the upper rock strata will be, mainly manifested by bending and subsidence. When caving of the main roof occurred for the first time, as shown in Figure 9, the displacement and deformation were mainly concentrated in the caving part. Although the displacement of the rock strata above the caving zone changed, the change was small; as excavation 


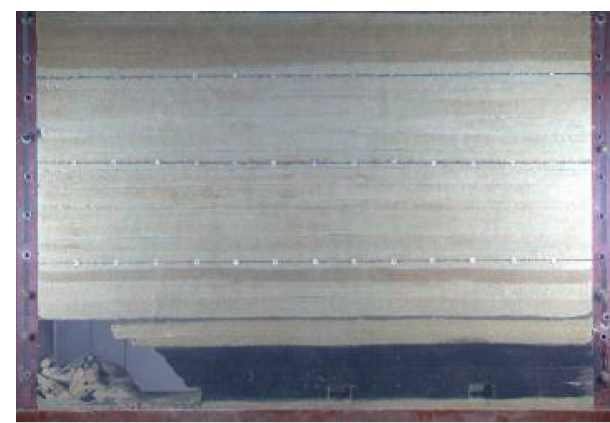

(a)

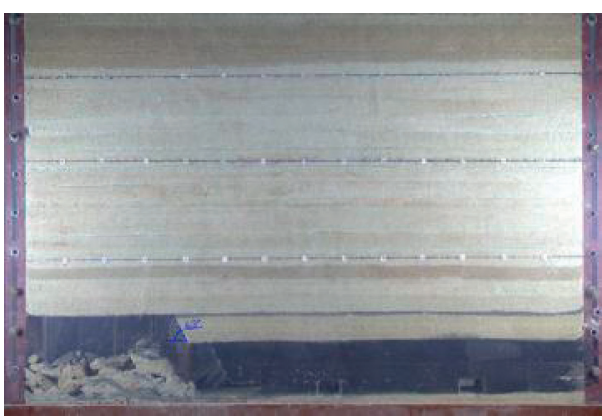

(c)

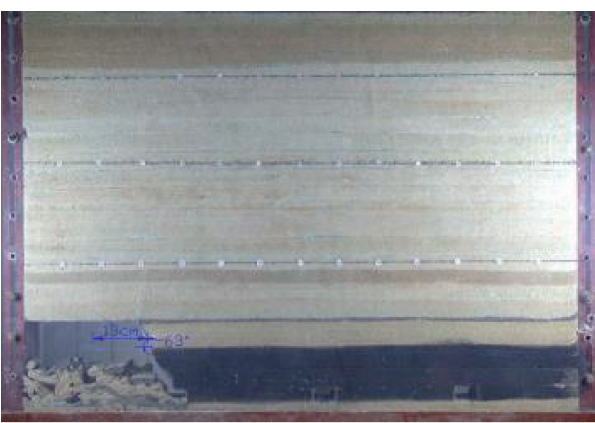

(b)

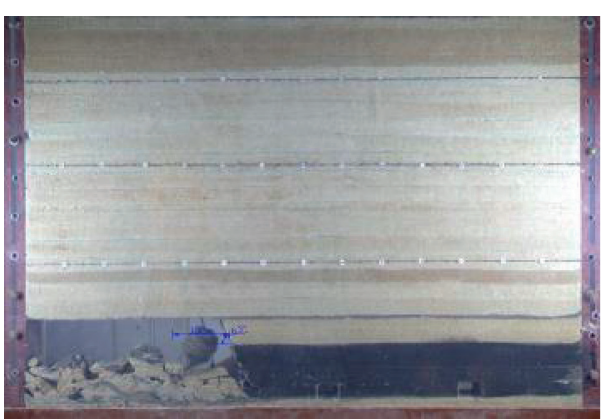

(d)

Figure 7: Breaking law of immediate roof. (a) Before the first break, (b) after the first break, (c) before the second break, and (d) after the second break.

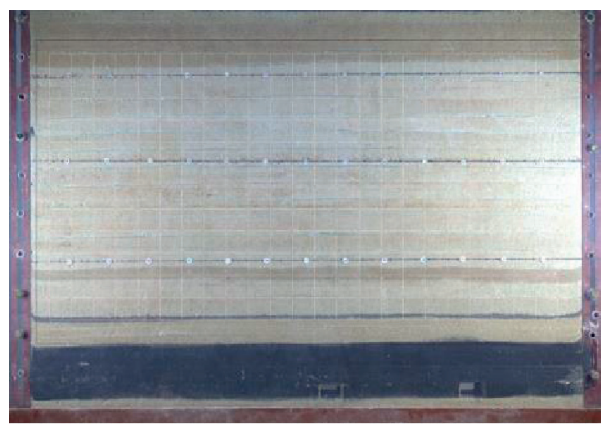

FIGURE 8: Grid partitioning.
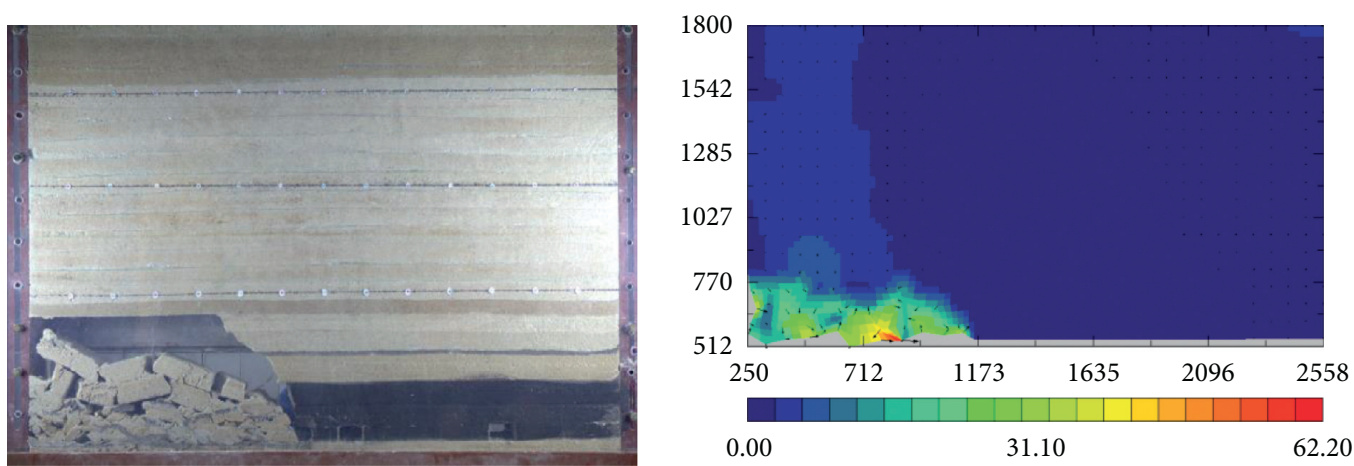

FIGURE 9: Model diagram and displacement vector cloud diagram of primary collapse of basic roof. 

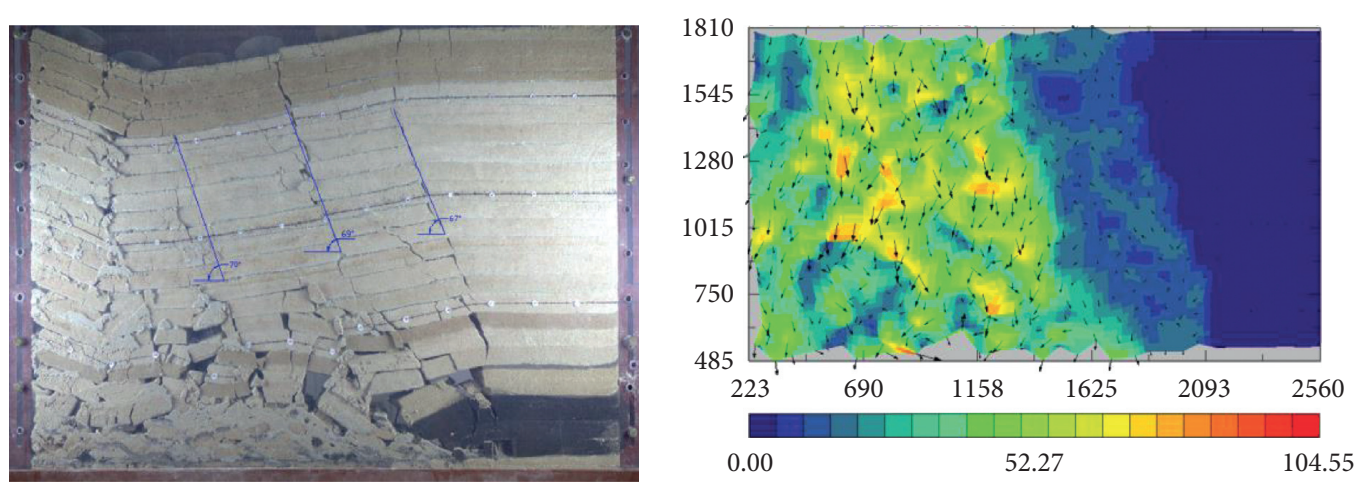

FIGURE 10: Model diagram and displacement vector cloud diagram of the third appearance of fracture zone.

continued, as shown in Figure 10, the crack zone first appeared and developed to the surface, forming obvious "three zones," namely, the caving zone, crack zone, and curved subsidence zone. Through the displacement vector flow field, with the vector direction obliquely to the lower left, it can be seen that the overlying rock strata on the working face are significantly curved and subsided, and the displacement of each rock stratum is increased compared with the initial caving; as shown in Figure 10, when the crack zone appeared for the second time, the previous crack was gradually closed, the existing goaf was compacted, and the maximum displacement became larger than when the fissure through the surface appeared for the first time; as working face advanced, as shown in Figure 10, the overlying rock strata developed through fissures for the third time. Through measurement, it was found that the angles of the three fractures in the strata were almost the same, about $69^{\circ}$.

\subsubsection{Subsidence Curve of the Fracture Measuring Line of the} Main Roof. As shown in the displacement curve in Figure 11, when caving of the main roof occurred for the first time, the three measuring lines hardly subsided, with the maximum subsidence value of $0.65 \mathrm{~cm}$, and the overlying rock strata hardly had any displacement; when the crack zone first appeared, as shown in Figure 12, the "three zones" began to appear. The third measuring line subsidence was larger, with the maximum subsidence value of $13.7 \mathrm{~cm}$, and the main roof of the overlying rock strata had a great displacement. When the crack zone appeared for the second time, as shown in Figure 13, the "three zones" appeared clearly. The overlying rock strata began to coordinate and subside synchronously. The first and second measuring lines had almost the same value of subsidence. The largest subsidence occurred on the third measuring line, with a maximum value of $16.1 \mathrm{~cm}$, and the third measuring line showed sinusoidal bending, mainly due to the irregular caving of the lower rock strata. When the crack zone appeared for the third time, as shown in Figure 14, the three measuring lines had large subsidence, with the maximum subsidence of $16.1 \mathrm{~cm}$, and the goaf at the back was gradually compacted and stabilized.

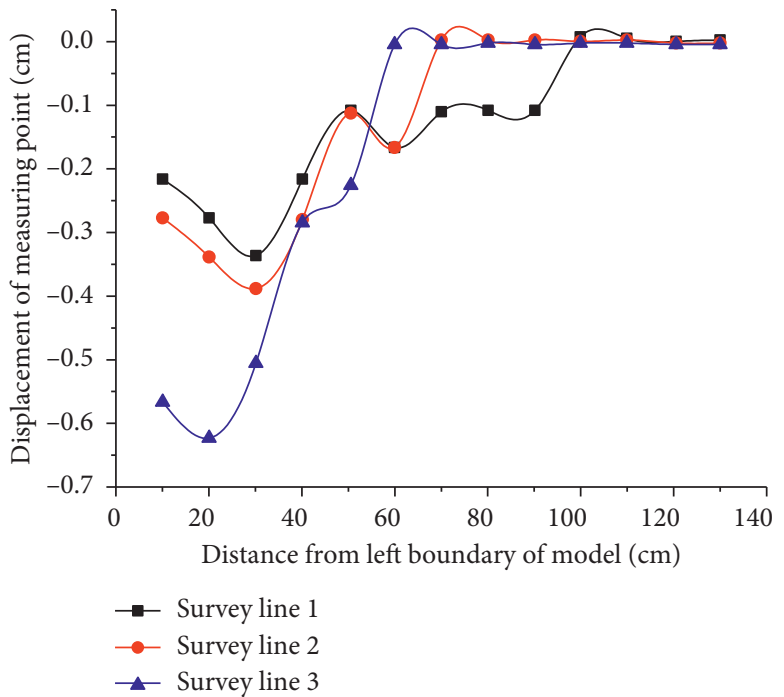

FIGURE 11: Displacement curve line of primary caving of basic roof.

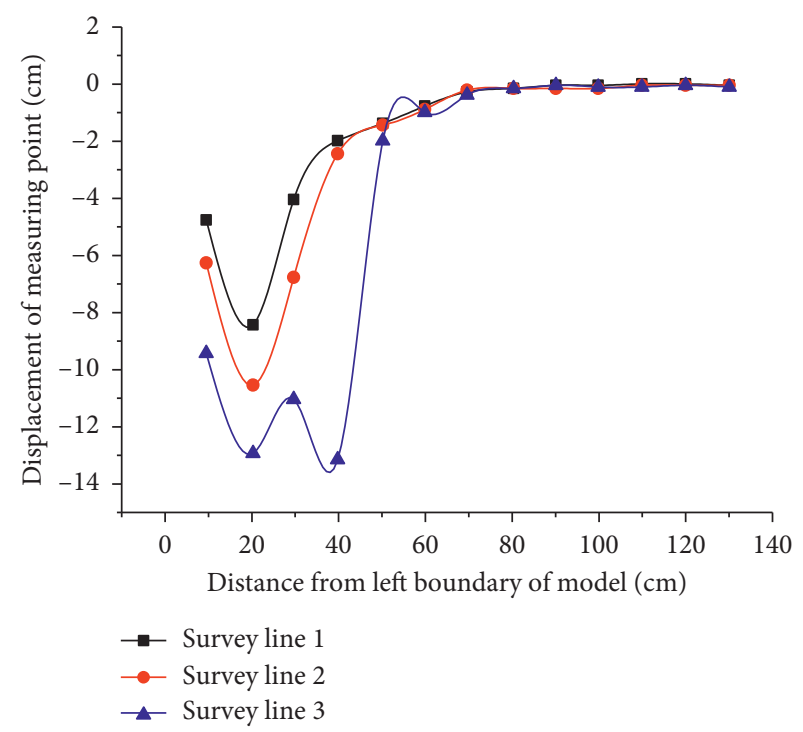

FIGURE 12: Displacement curve line of the first appearance of the fracture zone. 


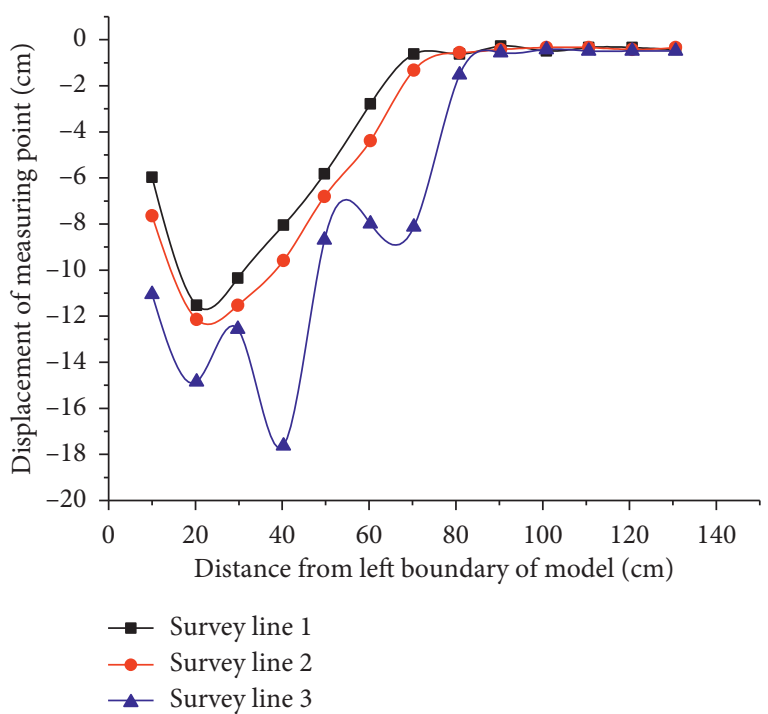

FIGURE 13: Displacement curve line of the second appearance of the fracture zone.

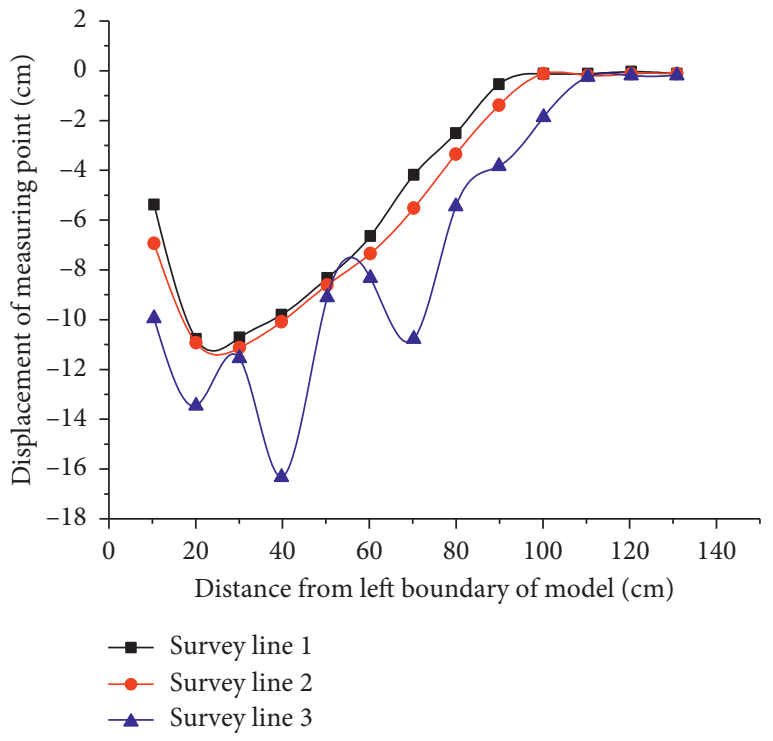

FIGURE 14: Displacement curve line of the third appearance of the fracture zone.

4.3. Key Strata Structure Analysis. According to the key strata theory, the rock strata that control the activity of some rock strata in the overlying rock strata of the stope or all rock strata to the surface are called the key strata, the former is called the inferior key strata, and the latter is called the main key strata. The deformation characteristics of the main key strata overlying the stope indicate that when the key strata subside and deform, the value of subsidence of all the overlying rock strata is synchronously coordinated; the fracture characteristics show that the fracture of key strata will cause the synchronous fracture of all overlying rock strata, leading to displacement of rock strata on a larger scale; its bearing characteristics show that the key strata take the form of "plate" (or simply "beam") as the main bearing body of all rock strata before fracture, become the masonry beam structure after fracture, and continue to become the bearing body. By observing the entire test process, it was found that the $7.8 \mathrm{~m}-22 \mathrm{~m}$ rock strata above the top coal were fractured, which had a greater impact on the overlying rock strata. After fracture, it directly caused the synchronous fracture of all the overlying rock strata, which was consistent with the characteristics of the key strata, so it was initially determined as the main key strata of the mine in the test area. The specific test process is shown in Figure 15.

As shown in Figure 15(a), it was the model before the key strata fracture with no significant fissure in the middle rock strata. As excavation continued, as shown in Figure 15(b), the key strata were fractured, and the crack penetrated to the surface, causing the synchronously coordinated subsidence of upper rock strata. After fracturing, a masonry beam structure was formed to continue to support the overlying rock strata. The subsidence angle of block $\mathrm{B}$ is $12^{\circ}$, the length is $16 \mathrm{~cm}$, and the length of block $\mathrm{C}$ is $15.5 \mathrm{~cm}$.

\section{Stress Analysis of Coal Pillars of the Lower Sections with Variable Angle of Topping}

Affected by the F6203 working face, the auxiliary gate roadway of the F6204 working face had more significant strata pressure, the surrounding rock on the side of the coal pillar was severely fractured, and a large-scale "net bag" phenomenon occurred. It can be inferred from the analysis of the technical conditions of auxiliary transportation along the gate roadway of F6204 working face: the caving of the hard roof in the goaf on the F6203 working face will lead to the formation of a long suspension roof difficult to cave outside the goaf on the side of the auxiliary gate roadway of the F6204 working face. The rotation deformation of the suspension roof beam and the overlying pressure of overhanging rock strata will greatly increase the supporting load of the auxiliary gate roadway of the F6204 working face, thereby making the serious fracture of the top of the auxiliary gate roadway of the F6204 working face, accompanied by the sound of "coal cannon" and the large amount of displacement on both sides and at the top and bottom.

The suspension roof in the goaf of F6203 working face has a great impact on the coal pillars between F6203 and F6024 working faces and the pressure of F6204 auxiliary roadway. In the test, three fissures at $30^{\circ}, 45^{\circ}$, and $60^{\circ}$ were prefabricated from the angle of auxiliary gate roadway of the F6204 working face to the side of F6203 goaf. During the mining process, caving of the overlying rock strata occurred along the prefabricated fissures. The overlying strata structure after caving is shown in Figure 16.

It can be seen from Figure 16 that as the mining proceeded from left to right in the model, the overlying rock strata formed Zone A along the $30^{\circ}$ prefabricated fissures, and the rock strata in Zone A were gradually separated for caving; the overlying rock strata formed Zone B along the $45^{\circ}$ prefabricated fissures, and the rock strata in Zone B were gradually separated; the overlying rock strata formed Zone $\mathrm{C}$ along the $60^{\circ}$ prefabricated fissures, and the rock strata in Zone $\mathrm{C}$ were gradually separated. 


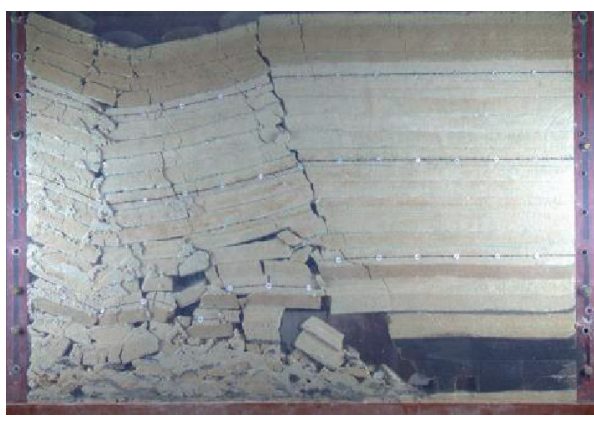

(a)

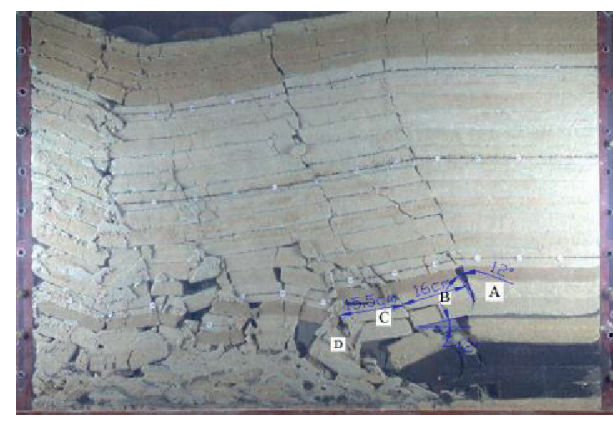

(b)

FiguRe 15: Model overview before and after key stratum breaking. (a) Before key stratum breaking and (b) after key stratum breaking.

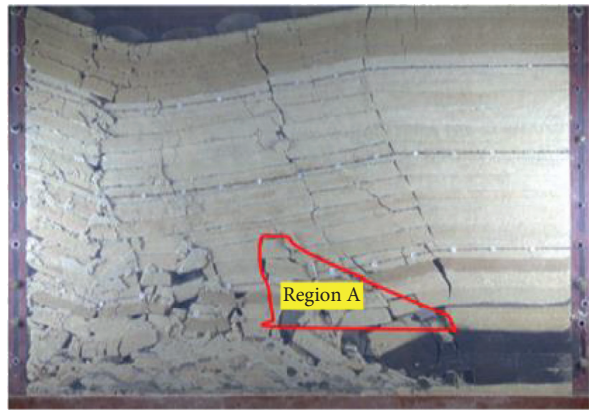

(a)

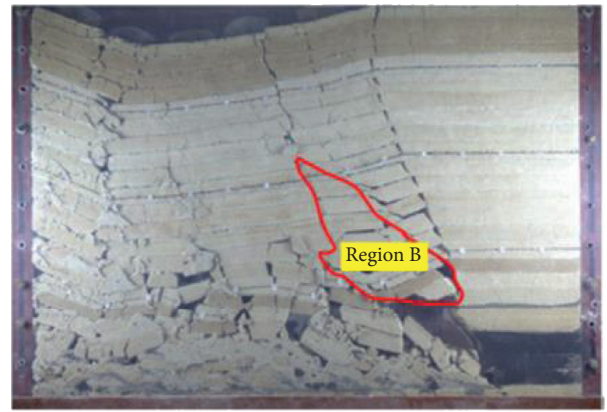

(b)

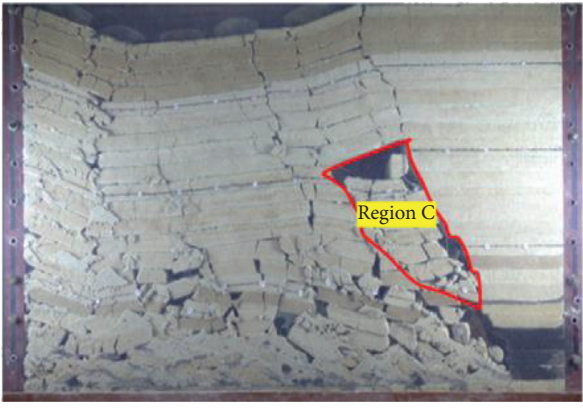

(c)

FiguRE 16: Structural form of overburden of topping fracturing. (a) Topping fracturing at $30^{\circ}$, (b) topping fracturing at $45^{\circ}$, and (c) topping fracturing at $60^{\circ}$.

5.1. Analysis of Stress Changes before and after Topping Fracturing at $30^{\circ}$. When the model was excavated to $98 \mathrm{~cm}$, the rock strata in Region A were almost completely separated, and Region A tended to stabilize. The overhanging rock strata were cut along the precracked surface, filling the caving space, eliminating the suspension roof phenomenon, and reducing the load and rotation deformation force of the cantilever beam.

It can be seen from Figure 17 that after the overlying rock strata were cut along the $30^{\circ}$ prefabricated fissure, the stresses of the A3 and A4 pressure cells decreased by $98 \%$ and $74 \%$, respectively, and the A3 and A4 pressure cells were located at the surrounding rock in auxiliary gate roadway of the F6204 working face; the stresses of the A5 and A6 pressure cells increased by $7 \%$ and $13 \%$, respectively. The A5 and A6 pressure cells were located in the unmined coal part on the right side of the F6204 auxiliary gate roadway. Through analysis, it can be found that the $30^{\circ}$ prefabricated fissure cutting greatly dissipated the stress concentration degree of the surrounding rock of the auxiliary gate roadway of the F6204 working face, so that the stress concentration was transferred to the depth of the unmined coal on the right side of the auxiliary gate roadway, which greatly improved surrounding rock stress environment of F6204 auxiliary gate roadway and fundamentally optimized the structural mechanical environment in the roadway.

5.2. Analysis of Stress Changes before and after Topping Fracturing at $45^{\circ}$. When the model was excavated to $104.8 \mathrm{~cm}$, the rock strata in Region B were almost completely 


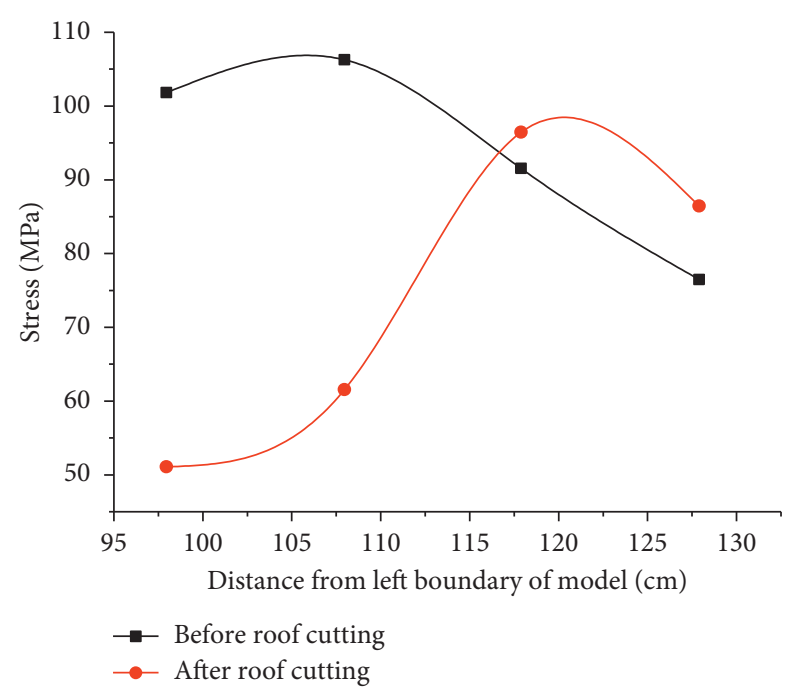

Figure 17: Before and after topping fracturing at $30^{\circ}$.

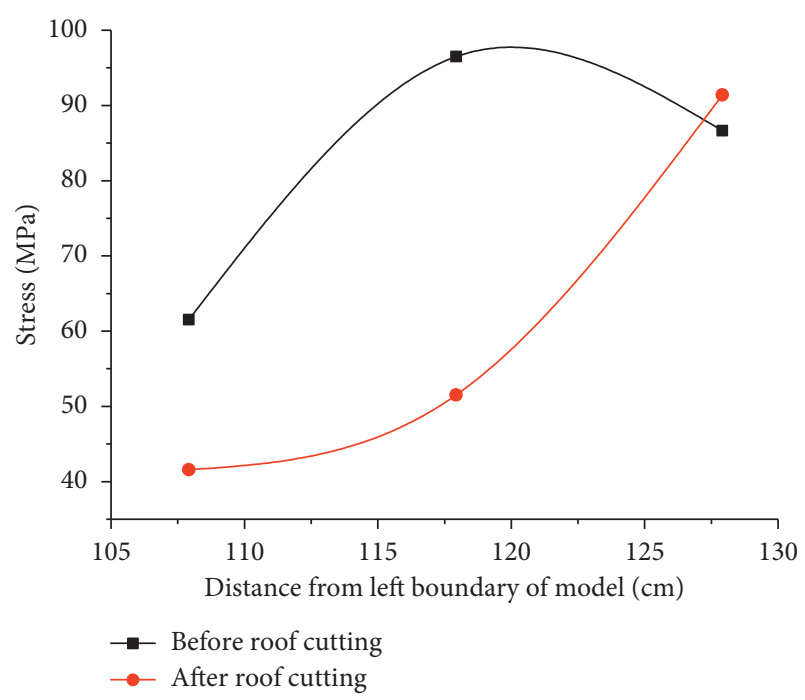

Figure 18: Before and after topping fracturing at $45^{\circ}$.

separated, and Region B tended to stabilize. The overhanging rock strata were cut along the precracked surface, filling the caving space, eliminating the suspension roof phenomenon, and reducing the load and rotation deformation force of the cantilever beam.

It can be seen from Figure 18 that after the topping of the overlying rock strata along the prefabricated fissure at $45^{\circ}$, the stress of the A4 pressure cell decreased by $49 \%$, the stress of the A5 pressure cell decreased by $87 \%$, and the stress of the A6 pressure cell increased by $6 \%$. It can be found through analysis that the $45^{\circ}$ prefabricated fissure topping greatly reduced the stress at the end of the auxiliary gate roadway of the F6204 working face, so that the stress is transferred to the depth of the unmined coal body.

5.3. Analysis of Stress Changes before and after Topping Fracturing at $60^{\circ}$. When the model was excavated to $121.8 \mathrm{~cm}$, the rock strata in Region C were almost completely

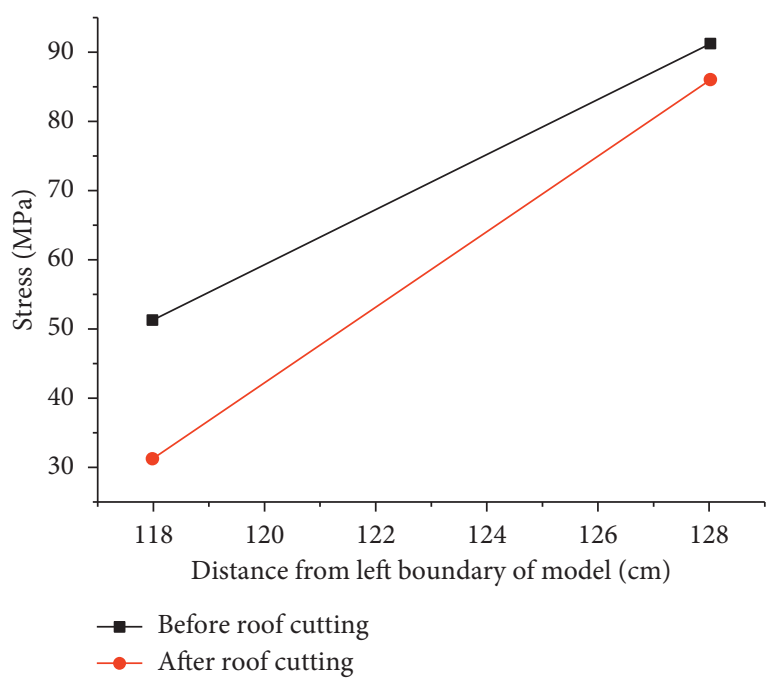

FIGURE 19: Before and after topping fracturing at $60^{\circ}$.

separated, and Region $\mathrm{C}$ tended to stabilize. The overhanging rock strata were cut along the precracked surface, filling the caving space, eliminating the suspension roof phenomenon, and reducing the load and rotation deformation force of the cantilever beam.

It can be seen from Figure 19 that after the topping of the overlying rock strata along the $60^{\circ}$ prefabricated fissure, the stress in the A5 pressure cell decreased by $63 \%$, and the stress in the A6 pressure cell decreased by $6 \%$. It can be found through analysis that the topping along $60^{\circ}$ prefabricated fissure reduced the stress at the end of the auxiliary gate roadway of the F6204 working face. The degree of reduction was small, and it may be affected by the right boundary of the model.

\section{Conclusion}

(1) The breaking distance of the immediate roof limit was about $13 \mathrm{~m}$, and the fracture angle was about $63^{\circ}$; upon the caving of main roof for the first time, the overlying rock strata hardly had any displacement; when the crack zone first appeared, the "three zones" began to appear, and the main roof of the overlying rock strata had great displacement; when the crack zone appeared for the second and third times, synchronously coordinated subsidence of overlying rock strata began to occur. The goaf at the back was gradually compacted and stabilized. The angles of the three cracks in the rock stratum were almost the same, about $69^{\circ}$.

(2) Before the key strata fractured, the "plate" structure was used as the main bearing body of all the rock strata. The key strata fractured, and the crack penetrated to the surface, causing synchronously coordinated subsidence of upper rock strata. After the fracture, the masonry beam structure formed and continued to support the overlying rock strata. 
(3) The rock strata at $7.8 \mathrm{~m}-22 \mathrm{~m}$ above the top coal had a great impact on the overlying strata after fracturing, which directly led to the synchronous fracturing of all overlying rock strata. This is in line with the characteristics of the key strata, so it was preliminarily determined as main key strata of the mine in the test area.

(4) Compared with $45^{\circ}$ and $60^{\circ}$ prefabricated fissures, it can be found that the $30^{\circ}$ prefabricated fissure topping greatly dissipated the stress concentration of the surrounding rock of the auxiliary gate roadway at the F6204 working face, so that the stress was transferred to the depth of the unmined coal on the right side of the auxiliary gate roadway, which greatly improved surrounding rock stress environment of F6204 auxiliary gate roadway and fundamentally optimized the structural mechanical environment in the roadway.

\section{Data Availability}

The data used to support the findings of this study are available from the corresponding author upon request.

\section{Conflicts of Interest}

The authors declare no conflicts of interest.

\section{Acknowledgments}

This work is supported by the National Natural Science Foundation of China, Grants nos. 51804302 and 51674250, China Postdoctoral Science Foundation, Grant no. 2019M652018, Major Program of National Natural Science Foundation of China, Grants nos. 51734009 and 51323004, and National Key Research and Development Projects of China, Grant no. 2019YFC1904304. The authors sincerely acknowledge the former researchers for their excellent works, which greatly assisted their academic study.

\section{References}

[1] F. Liu, Z.-G. Ma, P. Gong, and N. Cui, "Deformation mechanism of ending of surrounding rock in super-thick coal seam with thin bedrock," Journal of Mining \& Safety Engineering, vol. 35, no. 1, pp. 94-99, 2018.

[2] Z.-Q. Yin, G.-X. Xie, Z.-X. Hu, and C.-Q. Zhu, "Investigation on fracture mechanism of coal rock on three-point bending tests under different gas pressures," Journal of China Coal Society, vol. 41, no. 2, pp. 424-431, 2016.

[3] Z. Q. Yin, H.-F. Ma, H. F. Ma, Z. X. Hu, and Y. Zou, "Effect of static-dynamic coupling loading on fracture toughness and failure characteristics in marble," Journal of Engineering Science and Technology Review, vol. 7, no. 2, pp. 169-174, 2014.

[4] Y. Xue, T. Teng, F. Dang, Z. Ma, S. Wang, and H. Xue, "Productivity analysis of fractured wells in reservoir of hydrogen and carbon based on dual-porosity medium model," International Journal of Hydrogen Energy, vol. 45, no. 39, pp. 20240-20249, 2020.

[5] J. Liu, X. Liang, Y. Xue, K. Yao, and Y. Fu, "Numerical evaluation on multiphase flow and heat transfer during thermal stimulation enhanced shale gas recovery," Applied Thermal Engineering, vol. 178, Article ID 115554, 2020.

[6] Y.-N. Xiao, "Study of end structural stability of fully mechanized caving face," China Mining Magazine, vol. 19, no. 2, pp. 86-103, 2010.

[7] C.-P. Liu, "Practices on face end support technology for fully mechanized top coal caving mining face in deep inclined thick seam," Coal Science and Technology, vol. 33, no. 10, pp. 23-25, 2005.

[8] P.-J. Yang and C.-Y. Liu, "Structure forms of basic roof and reasonable supporting parameters in ends of fully-mechanized top caving face," Journal of Mining \& Safety Engineering, vol. 29, no. 1, pp. 26-32, 2012.

[9] X.-Q. Fang, R.-Q. Xu, and J.-J. Zhao, "Research on instability of the triangular coal alongside the goaf in a fully mechanized top-coal caving work face," Journal of China University of Mining \& Technology, vol. 40, no. 5, pp. 678-683, 2011.

[10] E. J. Sellers and P. Klerck, "Modeling of the effect of discontinuities on the extent of the fracture zone surrounding deep tunnels," Tunneling and Underground Space Technology, vol. 15, no. 4, pp. 463-469, 2000.

[11] S.-C. Zhou, D. Li, F.-W. Zhang, D.-F. Shen, D.-P. Zhou, and C.-Y. Guo, "Optimization analysis of drilling layout based on blasting releasing pressure and its application," Chinese Journal of Rock Mechanics and Engineering, vol. 32, no. 4, pp. 807-813, 2013.

[12] C.-P. Lu, D. Li, L.-M. Dou, and X.-R. Wu, "Controlled weakening mechanism of dynamic catastrophe of coal and rock and its practice," Journal of China University of Mining \& Technology, vol. 35, no. 3, pp. 301-305, 2006.

[13] M.-Y. Wei, E.-Y. Wang, X.-F. Liu, and C. Wang, "Numerical simulation of rockburst prevention effect by blasting pressure relief in deep coal seam," Rock and Soil Mechanics, vol. 32, no. 8, pp. 2539-2560, 2011.

[14] R.-G. Dai, "Prelimenary analysis of the natural law of caving down the hard roof of the 15-foot coal seam at the Tu-er-ping mine and its mine pressure," Journal of China Coal Society, vol. 2, no. 4, pp. 40-50, 1965.

[15] P. Gong, Z.-G. Ma, R.-C. Zhang, X.-Y. Ni, F. Liu, and Z.-M. Huang, "Surrounding rock deformation mechanism and control technology for gob-side entry retaining with fully mechanized gangue backfilling mining: a case study," Shock and Vibration, vol. 2017, Article ID 6085941, 15 pages, 2017.

[16] Z.-G. Wang, H.-W. Zhou, and H.-P. Xie, "Experimental study of the rule of overlying strata movement and breakage in deep mining," Journal of Experimental Mechanics, vol. 23, no. 6, pp. 503-510, 2008.

[17] H.-W. Wang, H.-W. Zhou, and J.-P. Zuo, "Application of optical measurement method in strata movement smiulation experiment," Journal of China Coal Society, vol. 31, no. 3, pp. 278-281, 2006.

[18] Y.-H. Li, R.-X. Jia, and S. Yang, "Optimized method for DSCM based on progressive displacement characteristics of geotechnical materials," Chinese Journal of Geotechnical Engineering, vol. 37, no. 3, pp. 1490-1496, 2015.

[19] S. Yang, Y. Li, X. Tang, and J. Liu, "Experimental simulation and numerical modeling of deformation and damage evolution of pre-holed sandstones after heat treatment," Computer Modeling in Engineering \& Sciences, vol. 122, no. 2, pp. 633-659, 2020.

[20] Y.-H. Li and H.-W. Jing, "Software development of a digital speckle correlation method and its application," Journal of China University of Mining \& Technology, vol. 37, no. 5, pp. 635-640, 2008. 
[21] D.-F. Yuan, C.-Y. Wang, and Y. Zhou, "Study on the law of the pressure of the fully mechanized mining face in deep mining," Coal Engineering, vol. 5, pp. 52-54, 2010.

[22] F. Luo, B.-S. Yang, and B.-B. Hao, "Mechanical properties of similar material under uniaxial compression and the strength error sources," Journal of Mining \& Safety Engineering, vol. 30, no. 1, pp. 93-99, 2013.

[23] Y.-B. Ning, H.-M. Tang, B.-C. Zhang, P.-W. Shen, G.-C. Zhang, and D. Xia, "Research on rock similar material proportioning test based on orthogonal design and its application in base friction physical model test," Rock and Soil Mechanics, vol. 41, no. 6, pp. 1-11, 2020.

[24] T.-Y. Li, J.-M. Zhao, and H.-Z. Zhou, "Mixture proportioning tests of rock similar materials based on the orthogonal methods," Journal of Water Resources and Architectural Engineering, vol. 16, no. 4, pp. 143-147, 2018. 